\title{
Isolation and Mode of Action of a Staphylococcin-like Substance Active Against Gram-positive and Gram-negative Bacteria
}

\author{
By O. A. KADER, H.-G. SAHL* AND H. BRANDIS \\ Institut für Medizinische Mikrobiologie und Immunologie der Universität Bonn, D-5300 Bonn 1, \\ Federal Republic of Germany
}

(Received 6 December 1983; revised 20 February 1984)

\begin{abstract}
Screening of non-phage group II Staphylococcus aureus strains for antagonistic substances revealed one particular strain, $S$. aureus $\mathrm{D} 91$, to excrete a substance with a wide spectrum of activity; both Gram-positive and Gram-negative bacteria were susceptible. The staphylococcin-like substance D91 produced by this strain was partially purified by column chromatography on Sephadex G-50, DEAE-cellulose, Phenyl Sepharose CL-4B and Sephadex G-200. A molecular weight of 76000 was estimated by gel filtration. The activity was heat sensitive but was not affected by hydrolytic enzymes except for pronase. The protein character of substance D91 was confirmed by gel electrophoresis and subsequent staining with Coomassie blue. The action exerted on sensitive bacteria was bacteriostatic rather than bactericidal. Biosynthesis of DNA, RNA, protein and polysaccharides were inhibited simultaneously in both Escherichia coli and Staphylococcus aureus. Active transport of glutamic acid was stopped in both $S$. cohnii and $E$. coli, whereas glucose uptake was inhibited in $E$. coli only. The substance induced a slow efflux of ${ }^{86} \mathrm{Rb}^{+}$from proloaded cells of $S$. cohnii and $E$. coli. The antagonistic activity of $S$. aureus D91 was eliminated by ethidium bromide at a rate of $47.6 \%$ suggesting that plasmids may be involved in its production.
\end{abstract}

\section{INTRODUCTION}

Bacteriocins are generally described as antagonistic bacterial agents with an active protein moiety; immunity of the producer strain to its own substance is genetically determined (Konisky, 1982). Bacteriocins of Gram-negative bacteria usually have a narrow spectrum of action restricted to closely related species, whereas those of Gram-positive organisms are active against many strains of Gram-positive species, but generally inactive against Gram-negative bacteria. Among numerous reports on antagonistic substances of staphylococci, only a few staphylococcins have been isolated and studied in more detail: staphylococcin 414 (Gagliano \& Hinsdill, 1970), staphylococcin 462 (Hale \& Hinsdill, 1973, 1975), which acts merely bacteriostatically, and staphylococcin Bac R1 (Rogolsky \& Wiley, 1977) whose production is encoded by a 56S exfoliative toxin plasmid. However, most work has been done on staphylococcin C55 (Dajani et al., 1970; Dajani \& Wannamaker, 1973a,b), and staphylococcin 1580 (Jetten et al., 1972; Jetten \& Vogels, $1972 a, b$; Weerkamp et al., 1977, 1978). The staphylococcins mentioned are generally high molecular weight aggregates (100000-500000) of undefined subunits and contain lipid or carbohydrate moieties besides the essential protein component. One of the first measurable effects which is caused by these staphylococcins is an immediate cessation of biosynthetic processes, suggesting the energy-transducing cytoplasmic membrane to be their primary target.

\footnotetext{
Abbreviations: AU, arbitrary units; CGY medium, casein hydrolysate/glucose/yeast extract medium; TSA(B), tryptone soya agar (broth).
} 
The fact that, so far, most work has concentrated on staphylococcins isolated from either phage group II Staphylococcus aureus or $S$. epidermidis strains prompted us to screen for bacteriocin production in non-phage group II $S$. aureus strains and to characterize the antagonistic substance of the strongest producer, $S$. aureus D91. This paper describes the purification and mode of action of a staphylococcin-like substance, D91, produced by this phage group I/III strain, which is inhibitory to both Gram-positive and Gram-negative bacteria.

\section{METHODS}

Source of bacteria. A total of 300 non-phage group II $S$. aureus strains isolated from clinical cases were obtained from the National Reference Laboratory for phage typing of staphylococci in the Institute of Medical Microbiology and Immunology of the University of Bonn. Staphylococcus cohnii 22, E. coli 11 and the other strains used for screening antagonistic activities and for recording the spectrum of inhibition originated from clinical specimens of the diagnostic routine laboratory of the same institute. The indicator strain $S$. aureus 19636 was from the American Type Culture Collection. Cultures for daily use were maintained on Tryptone Soya Agar (TSA; Oxoid). Stock cultures were kept on TSA in screw-capped tubes at $4^{\circ} \mathrm{C}$.

Screening for active strains. The method of deferred antagonism was used. The test organism was stabbed into TSA plates with a needle and incubated for $48 \mathrm{~h}$. The bacteria were then killed by exposure to chloroform, and the plates overlaid with the indicator cells in melted soft agar ( $0.4 \%)$. After $24 \mathrm{~h}$ incubation the plates were examined for growth inhibition zones. The indicator strains were $S$. aureus 55, S. aureus 16, S. aureus 19636, and $S$. cohnii 22. Strains inhibiting one or more of the indicator strains on solid media were tested for production of antagonistic substances in various liquid media: Nutrient Broth (Difco), Trypticase Soya Broth (Oxoid), Brain Heart Infusion Broth (Difco) and a medium containing casein hydrolysate $0.5 \%$, glucose $0.5 \%$, yeast extract $0.5 \%$ in $25 \mathrm{mM}$ $\mathrm{K}_{2} \mathrm{HPO}_{4}$ buffer, $\mathrm{pH} 7 \cdot 0$ (CGY).

Activity assay. The titre of the antagonistic substances produced in liquid media was estimated quantitatively. The highest dilution of the culture supernatant fluid yielding a definite zone of growth inhibition on indicator plates was defined as containing 1 arbitrary unit (AU) $\mathrm{ml}^{-1}$.

Spectrum of activity. To investigate the spectrum of the active strains, the same method as in the screening procedure was employed. The following were used as indicator organisms: 100 isolates of $S$. aureus, 40 isolates of streptococci, 20 isolates of E. coli, 20 isolates of Proteus sp., 20 isolates of Klebsiella sp. and 15 isolates of Pseudomonas sp.

Production of the inhibitory substance of $S$. aureus D91. The active substance was obtained by two methods.

(a) Strain D91 was grown in 2 litres of TSB for $48 \mathrm{~h}$; the supernatant obtained by centrifugation was brought to $90 \%$ ammonium sulphate saturation. The suspension was stirred for $30 \mathrm{~min}$ at $4^{\circ} \mathrm{C}$, centrifuged at $4000 \mathrm{~g}$ for $30 \mathrm{~min}$ and the precipitate dissolved in $100 \mathrm{ml} 25 \mathrm{~mm}-\mathrm{K}_{2} \mathrm{HPO}_{4}$ buffer, $\mathrm{pH} 7 \cdot 0$. This solution was considered as the crude preparation of the substance.

(b) Two hundred TSA plates were inoculated with an overnight culture of strain D91 (1 ml per plate) and incubated for $48 \mathrm{~h}$ at $37^{\circ} \mathrm{C}$. After addition of $1 \mathrm{ml} 2 \mathrm{M}-\mathrm{NaCl}$ to each plate, the growth was harvested and stirred overnight at room temperature. The suspension was then centrifuged at $4000 \mathrm{~g}$ for $15 \mathrm{~min}$, and the supernatant containing the substance concentrated to $100 \mathrm{ml}$ by ultrafiltration using a PM-10 membrane (Amicon).

Partial purification. The crude preparation of the substance $(100 \mathrm{ml})$ was applied to a Sephadex G-50 column $\left(90 \times 2 \mathrm{~cm}\right.$, flow rate $48 \mathrm{ml} \mathrm{h}^{-1}$ ) equilibrated with $25 \mathrm{mM}-\mathrm{K}_{2} \mathrm{HPO}_{4}, \mathrm{pH} 7 \cdot 0$. The active fractions were pooled and applied to a DEAE-cellulose (Serva) column $\left(35 \times 1.6 \mathrm{~cm}\right.$ ) equilibrated with $25 \mathrm{mM}-\mathrm{K}_{2} \mathrm{HPO}_{4}, \mathrm{pH} 7 \cdot 0$, and eluted with a $500 \mathrm{ml}$ linear gradient of $\mathrm{NaCl}(0-500 \mathrm{mM})$ in the same buffer. Active fractions were subjected to hydrophobic chromatography on Phenyl Sepharose CL-4B $\left(36 \times 0.6 \mathrm{~cm}\right.$, flow rate $\left.72 \mathrm{ml} \mathrm{h}^{-1}\right)$. The gel was equilibrated with $5 \mathrm{M}$-ammonium acetate. After application of the sample, the column was washed with 5 bed volumes of buffer. A linearly decreasing gradient of ammonium acetate $(5-0 \mathrm{M}$, total volume $500 \mathrm{ml})$ was then applied. Active fractions were concentrated to $3 \mathrm{ml}$ by ultrafiltration and applied to a Sephadex G-200 column $(80 \times 1.5 \mathrm{~cm}$, flow rate $6.5 \mathrm{ml} \mathrm{h}^{-1}$ ), equilibrated with $25 \mathrm{mM}-\mathrm{K}_{2} \mathrm{HPO}_{4}, \mathrm{pH} 7.0$.

Polyacrylamide gel electrophoresis (PAGE). A vertical gel electrophoresis system (BRL V 16-2) was used. The electrode buffer consisted of $0.6 \mathrm{~g}$ Tris and $2.8 \mathrm{~g}$ glycine per litre, $\mathrm{pH} 8.3$. A $7.5 \% \mathrm{gel}$ (acrylamide $/ N, N^{\prime}$-methylenebisacrylamide, $36: 1, \mathrm{w} / \mathrm{w}$ ) was prepared in $375 \mathrm{~mm}$-Tris/ $\mathrm{HCl}$ buffer, $\mathrm{pH} 8.9$, using $0.07 \%$ ammonium persulphate and $70 \mu \mathrm{l} N, N, N^{\prime}, N^{\prime}$-tetramethylethylenediamine per $100 \mathrm{ml}$. Electrophoresis was carried out at $20 \mathrm{~mA}$ for $4 \mathrm{~h}$. Gels were stained for protein with Coomassie blue.

Molecular weight determination. For molecular weight determination a Bio Gel P-300 (BioRad) column $\left(43 \times 1.2 \mathrm{~cm}\right.$, flow rate $\left.8.9 \mathrm{ml} \mathrm{h}^{-1}\right)$ was equilibrated with $100 \mathrm{mM}-\mathrm{K}_{2} \mathrm{HPO}_{4}, \mathrm{pH} 7.0$. The molecular weight of the substance was estimated by comparison with the elution profile of blue dextran (void volume), aldolase (158000), bovine serum albumin (67000), ovalbumin (43000) and chymotrypsinogen A (25000).

Sensitivity to enzymes. The following enzymes were tested individually at a concentration of $1 \mathrm{mg} \mathrm{ml}^{-1}$ for their ability to inactivate the substance: pronase (Merck), esterase (Sigma), carboxypeptidase A (pancreas, Serva), 
lipase (Aspergillus oryzae, Serva), lipase (wheat germ type 1, Sigma), $\beta$-amylase (barley malt, Serva), lysozyme (Sigma) and trypsin (bovine pancreas, Serva).

Elimination. Ethidium bromide (Merck) $\left(0 \cdot 1-60 \mu \mathrm{g} \mathrm{ml}^{-1}\right)$ was added to liquid cultures of $S$. aureus D91 to eliminate production of the inhibitory substance.

Viable counts. An overnight culture of the indicator strain $S$. aureus 19636 or $E$. coli 11 was diluted to approximately $10^{5}$ c.f.u. with fresh CGY medium and incubated at $37^{\circ} \mathrm{C}$ for $2 \mathrm{~h}$. The culture was then divided into equal volumes, one receiving the inhibitory substance at a concentration of $5 \mathrm{AU} \mathrm{ml}^{-1}$, the other receiving buffer only.

Samples of $100 \mu \mathrm{l}$ were suitably diluted, plated on TSA and read after $18 \mathrm{~h}$ for the number of c.f.u.

Incorporation of radioactive substrates. The effect of substance on the synthesis of DNA, RNA, protein and polysaccharide was studied by measuring the incorporation of the radioactive precursors $\left[{ }^{14} \mathrm{C}\right]$ thymidine, $\left[{ }^{3} \mathrm{H}\right]$ uracil, $\left[{ }^{3} \mathrm{H}\right]$ glucose, and $\left[{ }^{3} \mathrm{H}\right] g l u t a m i c$ acid or $\left[{ }^{3} \mathrm{H}\right] g l y c i n e$ or $\left[{ }^{14} \mathrm{C}\right]$ proline, respectively, in the acid-precipitable cell fraction.

CGY medium $(100 \mathrm{ml})$ was inoculated with $1 \mathrm{ml}$ of an overnight culture of the indicator strain (S. aureus 19636 or $E$. coli 11 ) and incubated for $5 \mathrm{~h}$ at $37^{\circ} \mathrm{C}$. The cells were then harvested by centrifugation and resuspended to their original volume in CGY medium modified according to the substrate to be tested: for amino acid incorporation casein hydrolysate was omitted; for thymidine and uracil incorporation the yeast extract concentration was reduced to $0.05 \%$, and for glucose incorporation its concentration lowered to $0.2 \mathrm{~mm}$. After $5 \mathrm{~min}$ incubation at $37^{\circ} \mathrm{C}$, the radioactive substrates $\left(1 \mu \mathrm{Ci} \mathrm{ml}^{-1} ; 37 \mathrm{kBq} \mathrm{ml}{ }^{-1}\right)$ were added to the cell suspensions. After 10-20 min, the cultures were divided into equal volumes, one receiving the inhibitory substance to a concentration of $5 \mathrm{AU} \mathrm{m}^{-1}$, the other buffer only. Immediately, samples were mixed with an equal volume of icecold $10 \%(\mathrm{w} / \mathrm{v}) \mathrm{TCA}$ containing the unlabelled substrate at $50 \mu \mathrm{g} \mathrm{m} \mathrm{m}^{-1}$. After $30 \mathrm{~min}$ incubation at $4{ }^{\circ} \mathrm{C}$ the samples were filtered through glass-fibre filters (Whatman GF/C), and washed with $10 \mathrm{ml} 2.5 \%$ TCA containing $1 \mathrm{M}-\mathrm{NaCl}$ and $50 \mu \mathrm{g}$ of the unlabelled substrate. The filters were dried and placed into $4 \mathrm{ml}$ scintillation fluid (Unisolve; Zinsser, Frankfurt/Main, FRG), and the radioactivity was then measured in a Packard liquid scintillation counter (Prias Model OL/PLD).

Uptake and efflux of glutamic acid. CGY medium $(50 \mathrm{ml})$ was inoculated with $1 \mathrm{ml}$ of an overnight culture of the indicator strain and incubated at $37^{\circ} \mathrm{C}$ for $5 \mathrm{~h}$. The growth was harvested, centrifuged and resuspended in $20 \mathrm{ml}$ of $0.5 \%$ glucose in $10 \mathrm{mM}^{-\mathrm{K}_{2}} \mathrm{HPO}_{4}, \mathrm{pH} 7 \cdot 0$, with addition of tetracycline $\left(100 \mu \mathrm{g} \mathrm{ml}^{-1}\right)$. After $5 \mathrm{~min}$ incubation at $37^{\circ} \mathrm{C},\left[{ }^{3} \mathrm{H}\right]$ glutamic acid $\left(1 \mu \mathrm{Ci} \mathrm{m}^{-1}\right)$ was added. The cell suspension was immediately divided into equal volumes, one receiving the inhibitory substance, the other buffer only. Efflux of $\left[{ }^{3} \mathrm{H}\right] \mathrm{glutamic}$ acid was tested by adding the inhibitory substance to cells preincubated with the radioactive substrate for 16 min $(S$. cohnii 22$)$ or $8 \mathrm{~min}$ ( $E$. coli 11 ). Samples of $0.8 \mathrm{ml}$ were poured on Millipore filters and washed with $5 \mathrm{ml} 200 \mathrm{mM}-\mathrm{K}_{2} \mathrm{HPO}_{4}$, $\mathrm{pH} 7.0$, containing the unlabelled substrate at $50 \mu \mathrm{g} \mathrm{ml}^{-1}$. The filters were then dried and counted in the scintillation counter.

Uptake of glucose. For measurement of glucose uptake the cells were resuspended in the same medium as used for glucose incorporation. $\left[{ }^{3} \mathrm{H}\right] \mathrm{Glucose}\left(1 \mu \mathrm{Ci} \mathrm{ml}{ }^{-1}\right)$ was added after $5 \mathrm{~min}$, and the procedure described above for glutamic acid was followed.

${ }^{86} \mathrm{Rb}^{+}$efflux. Medium $(50 \mathrm{ml})$ containing casein hydrolysate $0.5 \%$, glucose $0.5 \%$, yeast extract $0 \cdot 2 \%, \mathrm{KCl} 10 \mu \mathrm{M}$ and ${ }^{86} \mathrm{Rb}^{+} 1 \mu \mathrm{Ci} \mathrm{ml}^{-1}\left(37 \mathrm{kBq} \mathrm{ml}^{-1}\right)$ (final concentration $8 \mathrm{mM}$ ) in $10 \mathrm{mM}-\mathrm{Na}_{2} \mathrm{HPO}_{4}$ buffer, pH $7 \cdot 0$, was inoculated with $1 \mathrm{ml}$ of an overnight culture of the indicator strain in the same medium. After $3 \mathrm{~h}$ incubation at

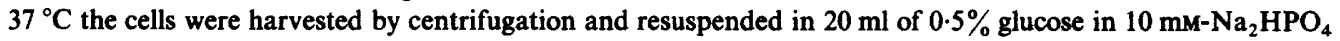

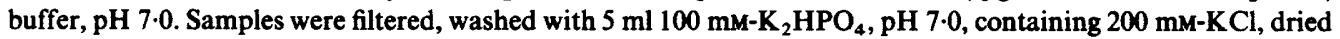
and the radioactivity counted.

Chemicals. All radiochemicals were purchased from Amersham Buchler, Braunschweig, and basic-grade chemicals from Merck.

\section{RESULTS}

\section{Screening of antagonistic strains}

Three hundred isolates of non-phage group II Staphylococcus aureus were tested against four staphylococcal indicator strains previously selected for their susceptibility to antagonistic substances. Fifteen strains $(5 \%)$ produced inhibition zones on TSA plates, zone diameters varying among the individual indicator strains. Five strains were able to produce small quantities of their antagonistic substances in liquid media; $S$. aureus D91 with the phage pattern $6 / 47 / 54 / 75 / 77 / 81 / 83 \mathrm{~A} / 84 / 85 /+$ was the strongest producer and was therefore selected for further study. The activity was detected both in the culture supernatant $(85 \%)$ and in the pellet $(15 \%)$. 
Table 1. Spectrum of activity of $S$. aureus $D 91$ in the deferred antagonism test

$\begin{array}{lcc}\text { Test organism } & \begin{array}{c}\text { No. of strains } \\ \text { tested }\end{array} & \begin{array}{c}\text { No. of strains } \\ \text { sensitive }\end{array} \\ \text { Staphylococcus aureus } & 100 & 100 \\ \text { Streptococci, serological group A } & 10 & 10 \\ \text { serological group B } & 10 & 0 \\ \text { serological group C } & 10 & 10 \\ \text { serological group G } & 4 & 4 \\ \text { other serological groups } & 6 & 2 \\ \text { Escherichia coli } & 20 & 12 \\ \text { Proteus sp. } & 20 & 20 \\ \text { Pseudomonas sp. } & 15 & 5 \\ \text { Klebsiella } \text { sp. } & 20 & 0\end{array}$

Spectrum of activity of $S$. aureus $D 91$

Staphylococcus aureus D91 inhibited all the $S$. aureus strains as well as many streptococcal strains in the deferred antagonism test. Its spectrum of activity was not restricted to Gram-positive organisms, but included strains of Proteus sp., E. coli and Pseudomonas sp. (Table 1).

Production of the antagonistic substance by $S$. aureus D91

Comparison of different growth media at several $\mathrm{pH}$ values and temperatures showed that the highest concentration of the antagonistic substance (termed D91) produced by $S$. aureus D91 was obtained in TSB at pH 7.0, after $48 \mathrm{~h}$ incubation at $37^{\circ} \mathrm{C}$ in aerobic culture. A 2 litre culture grown under these conditions yielded approximately $6400 \mathrm{AU}$ after precipitation of the substance with $90 \%$ saturated ammonium sulphate. Alternatively, the substance was obtained by harvesting the cell growth from 200 TSA plates $\left(48 \mathrm{~h}, 37^{\circ} \mathrm{C}\right)$ with $2 \mathrm{M}-\mathrm{NaCl}$. Although the total activity was $50 \%$ below that obtained in TSB, the crude preparation was less contaminated with medium components, and therefore preferred for further purification.

\section{Purification of the substance D91}

The purification was performed as described in Methods. On Sephadex G-50 the activity was eluted from the column in the void volume peak, and thus separated from the bulk media components. Further purification was achieved on a DEAE-cellulose ion exchange column and subsequent hydrophobic chromatography, where binding of the substance was promoted by $5 \mathrm{M}$ ammonium acetate. With decreasing salt concentrations, the active substance was eluted in the range of $1 \mathrm{M}$-ammonium acetate (Fig. 1). This step removed a high percentage of the contaminating peptides, whereas the subsequent purification step on the Sephadex G-200 gel filtration column proved less effective. The resulting preparation contained $15 \%$ of the activity of the original crude material and was only partially purified. In PAGE without SDS, several prominent bands appeared. The activity corresponded to a diffuse Coomassie-blue stained band running with a constant $R_{F}$ value of $0 \cdot 8$. Treatment with SDS or $2 \mathrm{M}$-urea resulted in total loss of activity. Thus an attempt to correlate the activity to one of the bands obtained in SDS-PAGE failed, and the molecular weight of the substance could only be estimated by gel filtration.

\section{Characterization of substance D91}

The substance was not dialysable. The molecular weight obtained by gel filtration chromatography was 76000 . Substance D91 was resistant to the action of many hydrolytic enzymes such as trypsin, lipase, amylase and esterase, but was slowly inactivated by pronase $(50 \%$ loss of activity in $2 \mathrm{~h}$ ). It was stable over a wide $\mathrm{pH}$ range $(1.5-8)$ and was not destroyed by chloroform, but it was inactivated within $10 \mathrm{~min}$ by heating to $80^{\circ} \mathrm{C}$. It was stable on storage at $4{ }^{\circ} \mathrm{C}$ and towards repeated freezing and thawing.

As reported for many staphylococcins like C55 and Bac R1 (Dajani \& Taube, 1974; Warren et $a l ., 1974)$, the production of substance D91 could be eliminated by curing agents known to 


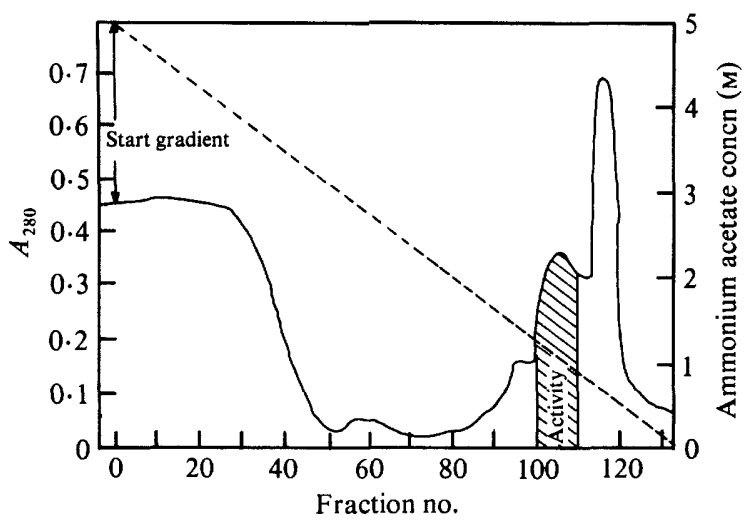

Fig. 1. Hydrophobic chromatography of the staphylococcin-like substance D91 on Phenyl Sepharose CL-4B. The active fractions eluted from the DEAE-cellulose column were brought to $5 \mathrm{M}$ with respect to ammonium acetate and applied to a Phenyl Sepharose CL-4B column previously equilibrated with the same buffer. After intensive washing with starting buffer, the substance was eluted with a linearly decreasing gradient of ammonium acetate. The activity eluted at approximately $1 \mathrm{M}$-ammonium acetate.,$- A_{280} ;---$, ammonium acetate gradient.
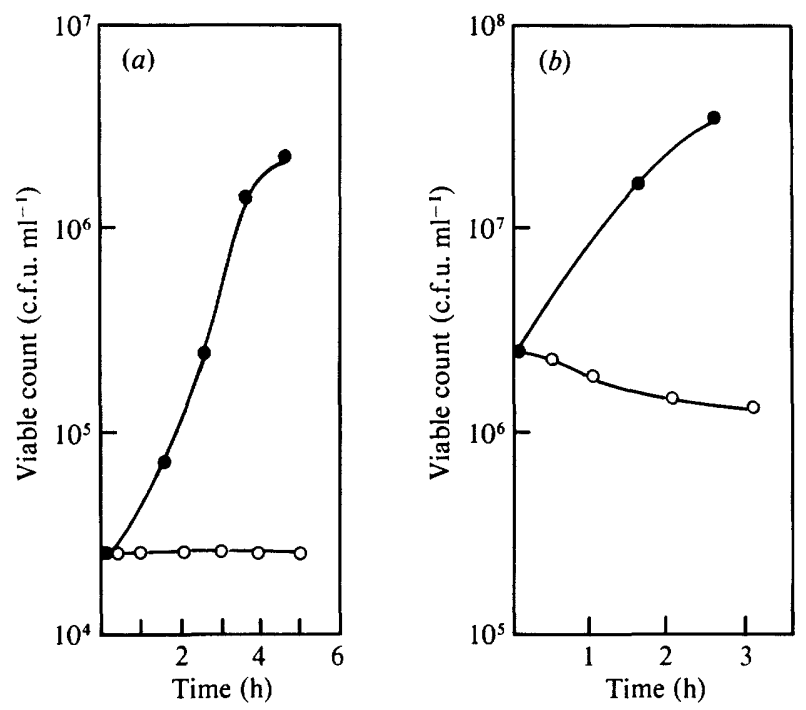

Fig. 2. Effect of the staphylococcin-like substance D91 on the viable count of $S$. aureus $19636($ a) and E. coli $11(b)$. Control; $\mathrm{O}$, cells treated with substance D91 $\left(5 \mathrm{AU} \mathrm{ml}^{-1}\right)$.

eliminate plasmids. Out of a total of 800 colonies of strain D91, $380(47.5 \%)$ lost their ability to produce the substance after treatment with ethidium bromide at $30 \mu \mathrm{g} \mathrm{ml}^{-1}$.

\section{Mode of action of substance $D 91$}

Recording the viable count of an indicator cell suspension after treatment with the partially purified substance $\left(5 \mathrm{AU} \mathrm{ml}^{-1}\right)$ suggested a bacteriostatic rather than a bactericidal action (Fig. 2). With the $S$. aureus indicator strain 19636 no lethal activity could be demonstrated after $5 \mathrm{~h}$ incubation, while the number of viable $E$. coli 11 cells decreased by $70 \%$ within $3 \mathrm{~h}$.

The effect of the substance on macromolecular synthesis was investigated in $S$. aureus 19636 and $E$. coli 11 . DNA, RNA, protein and polysaccharide synthesis were rapidly inhibited as 

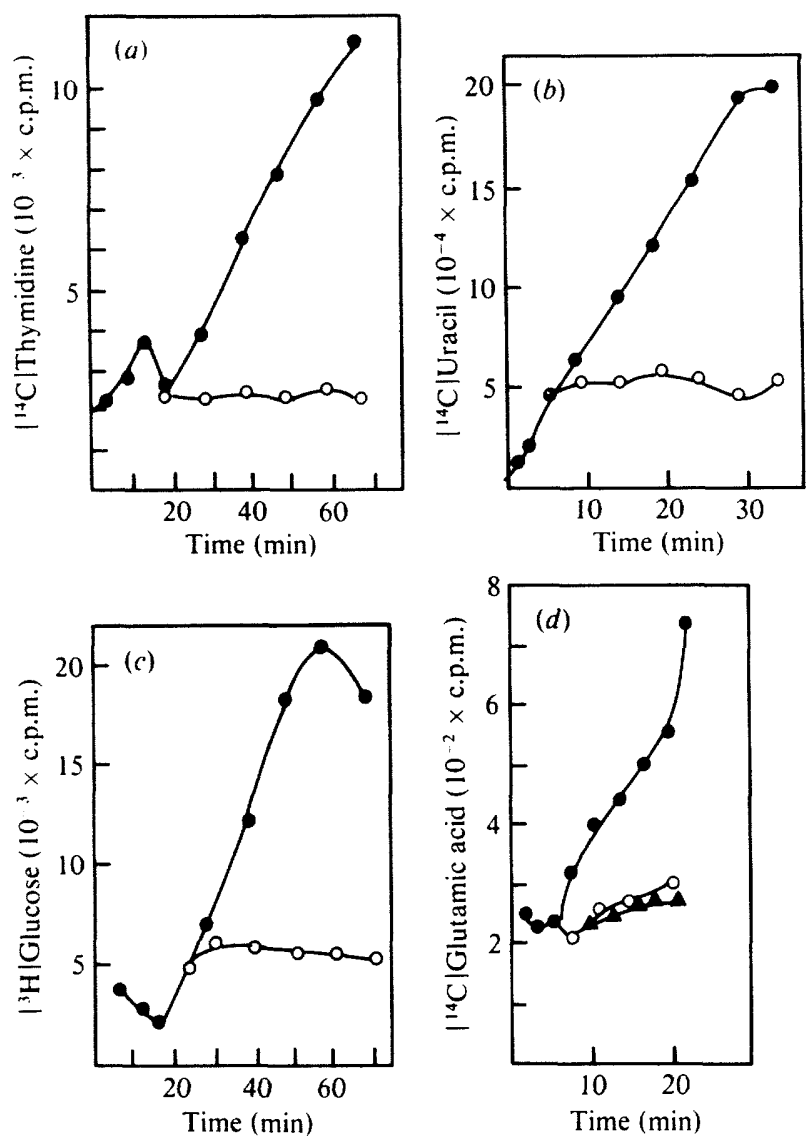

Fig. 3. Effect of the staphylococcin-like substance D91 on macromolecular synthesis in $S$. aureus 19636. After incubation in the presence of radioactive substrate $\left(1 \mu \mathrm{Ci} \mathrm{ml}^{-1}\right)$, the culture was divided into a control tube $(O)$ and an assay tube $(O)$, which received the staphylococcin-like substance D91 $\left(5 \mathrm{AU} \mathrm{m} \mathrm{m}^{-1}\right)$; in the experiment shown in $(d)$ an additional control was run containing tetracycline $\left(100 \mu \mathrm{g} \mathrm{ml}^{-1}\right)(\Delta)$. Incorporation into the acid-precipitable fraction was measured at timed intervals.

indicated by the cessation of incorporation of the labelled precursors into the acid-insoluble fraction (Figs 3 and 4). Glutamic acid uptake was only partially inhibited in S. cohnii 22 (Fig. $5 a$ ), while glucose uptake was not affected (Fig. $6 a$ ). In E. coli 11, glutamic acid uptake was not only completely blocked but the results obtained with treated cells suggested a $50 \%$ efflux of the preaccumulated amino acid (Fig. $5 b$ ). In contrast to $S$. cohnii 22 , glucose uptake by $E$. coli 11 was considerably inhibited by substance D91 (Fig. 6b). This may explain the lower survival percentage of $E$. coli 11 treated with the substance. The fact that a staphylococcin could have different modes of action on various susceptible cells was observed by Hale \& Hinsdill (1975). They reported that staphylococcin $\mathbf{4 5 2}$ was lethal to some strains, while only growth-inhibitory to others.

Addition of substance D91 to susceptible cells preloaded with ${ }^{86} \mathbf{R b}^{+}$resulted in a slow and incomplete efflux of ${ }^{86} \mathrm{Rb}^{+}$from the treated cells (Fig. 7). With $80 \%$ loss in $25 \mathrm{~min}$, the efflux from $S$. cohnii 22 cells was faster than that from $E$. coli 11 cells $(35 \%$ loss in $50 \mathrm{~min})$. Jetten \& Vogels $(1972 b)$ reported that the addition of staphylococcin 1580 to susceptible cells resulted in loss of more than $90 \%$ of intracellular ${ }^{86} \mathrm{Rb}^{+}$within $4 \mathrm{~min}$.

The presence of $100 \mathrm{mM}$-ammonium acetate or $\mathrm{KCl}$ decreased the inhibitory effect of the substance on glutamic acid uptake and prevented efflux of ${ }^{86} \mathrm{Rb}^{+}$from the treated cells. On the 

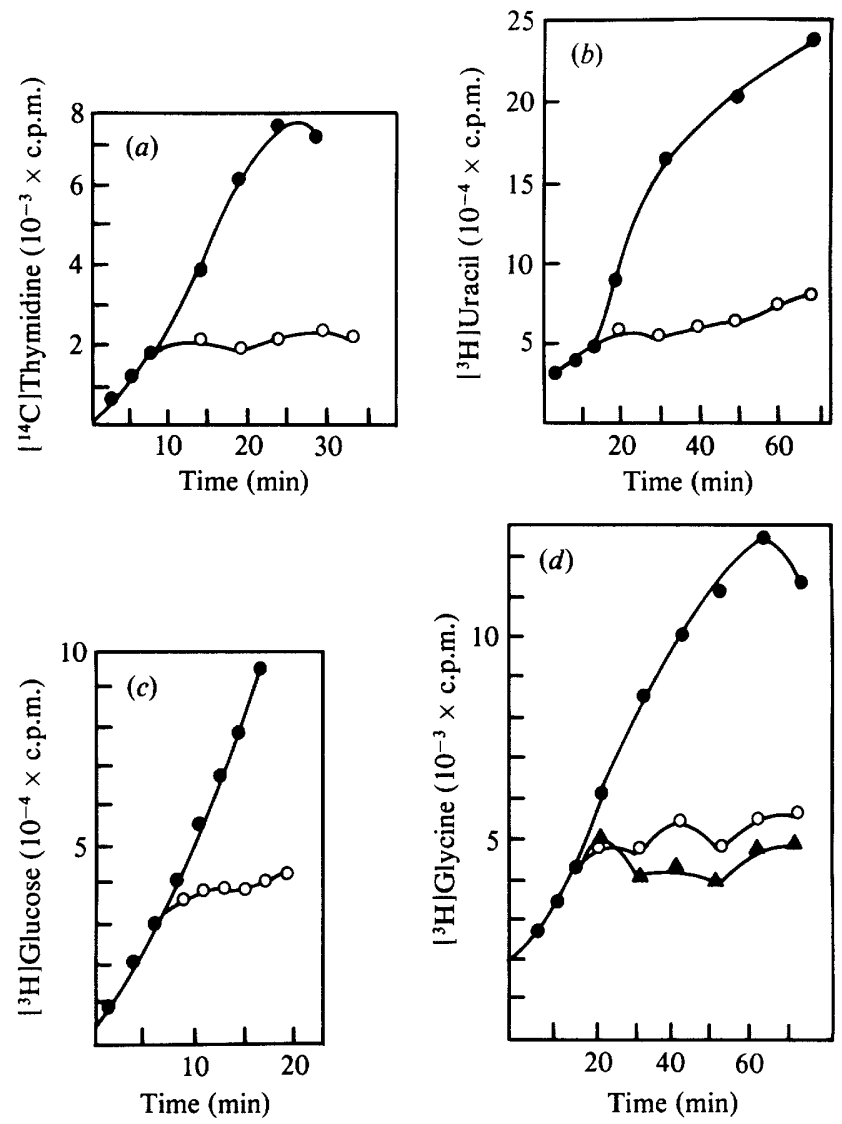

Fig. 4. Effect of the staphylococcin-like substance D91 on macromolecular synthesis in E. coli 11. For further details see Fig. 3.
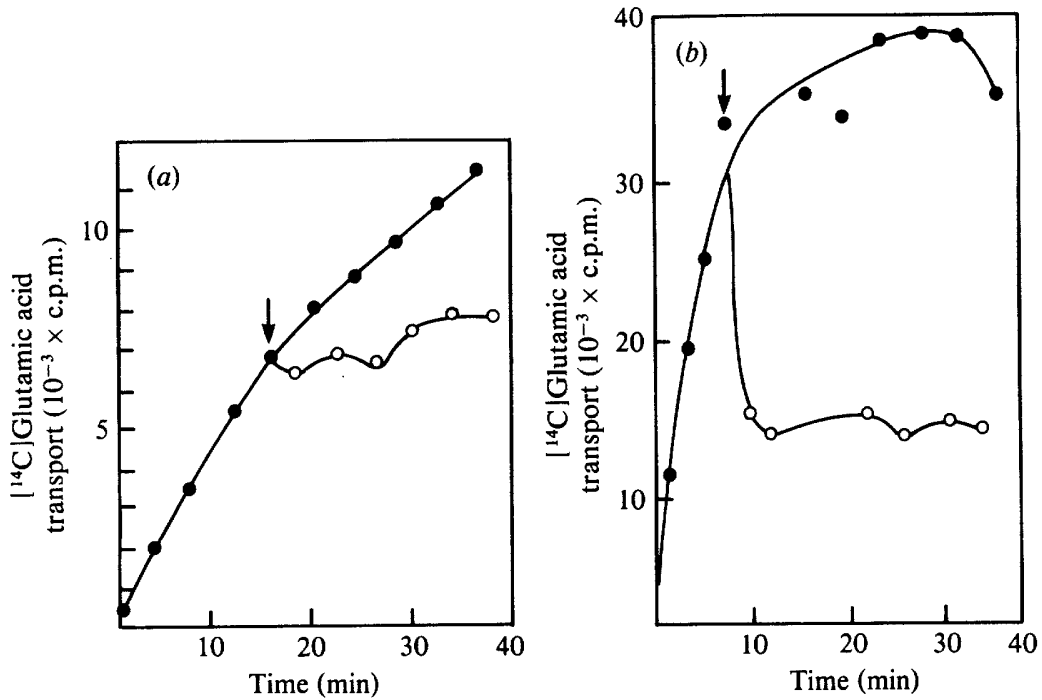

Fig. 5. Effect of the staphylococcin-like substance D91 on glutamic acid accumulation in S. cohnii 22 (a) and E. coli $11(b)$. , Control; O, substance D91 $\left(10 \mathrm{AU} \mathrm{ml}^{-1}\right)$ added (addition indicated by arrows). 

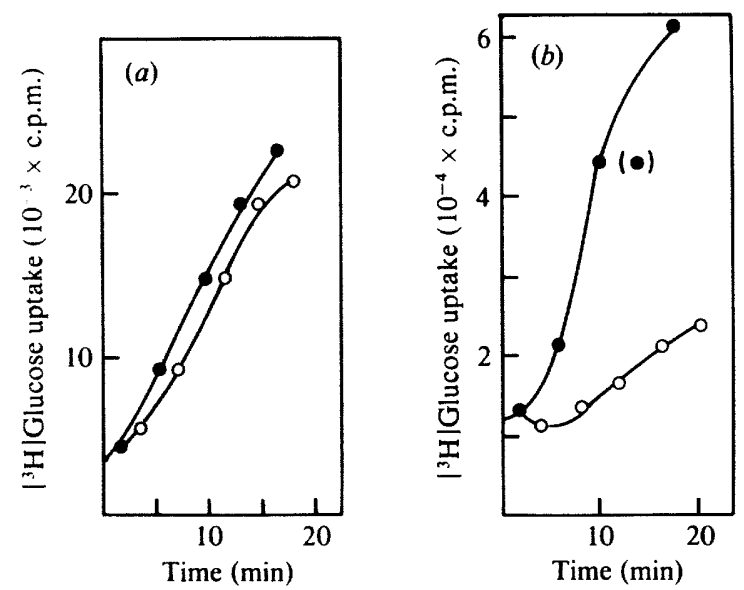

Fig. 6. Effect of the staphylococcin-like substance D91 on glucose uptake in $S$. cohnii $22(a)$ and $E$. coli $11(b)$. After the addition of $\left[{ }^{3} \mathrm{H}\right]$ glucose $\left(1 \mu \mathrm{Ci} \mathrm{ml}^{-1}\right)$, the culture was immediately separated into equal parts: one part received substance $\mathrm{D} 91\left(10 \mathrm{AU} \mathrm{ml}^{-1}\right)(\mathrm{O})$ while buffer was added to the control $(O$; the point in parentheses was not considered in drawing the curve).
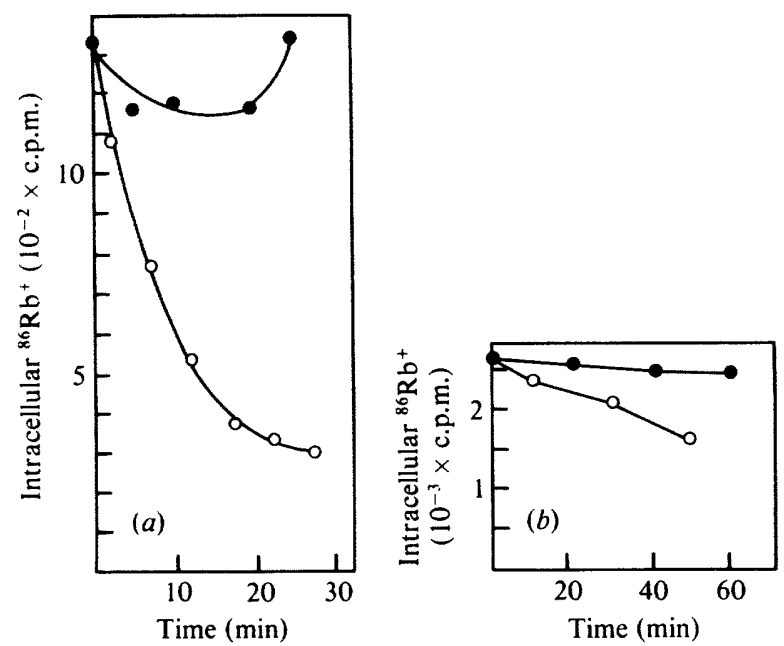

Fig. 7. Effect of the staphylococcin-like substance D91 on the intracellular ${ }^{86} \mathrm{Rb}^{+}$concentration in $S$. cohnii $22(a)$ and $E$. coli $11\left(\right.$ b). The cells were grown in $50 \mathrm{ml}$ medium containing $1 \mu-\mathrm{Ci}^{86} \mathrm{Rb}^{+} \mathrm{ml}^{-1}$ (see Methods), harvested by centrifugation after $3 \mathrm{~h}$ growth and resuspended in $20 \mathrm{ml}$ of $10 \mathrm{mM}-\mathrm{Na}_{2} \mathrm{HPO}_{4}$ buffer, pH $7 \cdot 0$, supplemented with $0.5 \%$ glucose. The cell suspension was divided into equal parts, one of which received substance D91 $(10 \mathrm{AU} \mathrm{ml}-1)(\mathrm{O})$, while buffer was added to the control $\left(\mathrm{O}^{-}{ }^{86} \mathrm{Rb}^{+}\right.$ radioactivity was measured in washed cells at timed intervals.

other hand inhibition of macromolecular synthesis was not influenced by similar salt concentrations.

\section{DISCUSSION}

Of the non-phage group II $S$. aureus strains screened in this study, $5 \%$ showed antagonistic activity against staphylococcal strains, indicating that the production of inhibitory substances is not only restricted to phage group II $S$. aureus strains. 
The antagonistic substance D91 isolated from $S$. aureus D91 exists in both a cell-associated and an extracellular form, as is known for other bacteriocins, including staphylococcins 1580 (Jetten et al., 1972) and C55 (Dajani et al., 1970) as well as colicins K, A, and E1 (Dandeu, 1971). Like staphylococcin 1580 (Jetten et al., 1972) and colicins E2 and E3 (Herschman \& Helinski, 1967), substance D91 could be extracted from the cells by $2 \mathrm{M}-\mathrm{NaCl}$.

Substance D91 had a molecular weight of 76000 as estimated by gel filtration. The fact that it could not be purified to homogeneity prevented chemical analysis, but on polyacrylamide gel electrophoresis the inhibitory activity corresponded to a band that stained with Coomassie blue. This evidence, together with the fact that the activity was destroyed by pronase, suggests the presence of a biologically active protein component.

The production of the substance is probably controlled by a plasmid, since elimination was effected by ethidium bromide.

Bacteriocins produced by Gram-positive organisms generally have a wide spectrum of activity, but do not inhibit Gram-negative organisms. However, Morris et al. (1978) found that, besides Gram-positive bacteria, seven strains of Neisseria gonorrhoeae were susceptible to Bac R1, a staphylococcin produced by a phage group II $S$. aureus strain. The staphylococcinlike substance D91 is remarkably different from other staphylococcins in that it is active on many Gram-negative organisms such as E. coli, Proteus and Pseudomonas strains, apart from staphylococci and streptococci. Thus it shows some similarities to the group of cationic proteins isolated from human neutrophil leucocytes. These proteins have a molecular weight of 25000 28000 and are active against Gram-positive and Gram-negative organisms (Odeberg \& Olsson, 1976).

Like many other bacteriocins, e.g. staphylococcin 1580 (Jetten \& Vogels, 1972b), staphylococcin C55 (Dajani et al., 1970), staphylococcin 462 (Hale \& Hinsdill, 1975), staphylococcin 414 (Gagliano \& Hinsdill, 1970), and colicins E1 and K (Konisky, 1982) the bacteriocin-like substance D91 inhibited simultaneously protein, DNA, RNA, and polysaccharide synthesis. This suggests that none of these processes is affected primarily, but that the energy-transducing cytoplasmic membrane is the biological target. The substance induced a slow but incomplete efflux of ${ }^{86} \mathrm{Rb}^{+}$from preloaded cells, indicating that the membrane potential may be impaired but not totally abolished. This may explain the non-lethal action of the substance on indicator cells, since retention of a certain internal $\mathrm{K}^{+}$ion concentration has been reported to protect cells from lethal effect when treated with staphylococcin 1580 (Weerkamp et al., 1977). Survival of cells treated with colicin E1 or $\mathrm{K}$ when incubated in media with $\mathrm{K}^{+}$and $\mathrm{Mg}^{2+}$ concentrations corresponding to the intracellular level has also been reported (Kopecky et al., 1975).

The effect of substance D91 on glutamic acid and glucose transport differed between staphylococcal and $E$. coli indicator strains. In $S$. cohnii, glucose uptake was not inhibited. This could be explained by the fact that glucose uptake in staphylococci is mediated by group translocation, while in $E$. coli the proton-motive force is thought to be involved in glucose transport (for a review see Rosen \& Kashket, 1982). Active transport of glutamic acid in staphylococci is reported to be an electroneutral glutamate $/ \mathrm{H}^{+}$symport mechanism driven by $\Delta \mathrm{pH}$, which may explain why it was only partially inhibited by substance D91. In E. coli glutamic acid uptake is a $\mathrm{Na}^{+}$symport system with shock-sensitive periplasmic binding proteins increasing the affinity of the system for the substrate (see also Rosen \& Kashket, 1982). Release of glutamic acid bound to these proteins could explain the apparent loss of radioactive label after addition of the substance to sensitive $E$. coli cells.

Hale \& Hinsdill (1973) described a staphylococcin with a bacteriostatic action. These authors suggested that the interaction between the staphylococcin and susceptible cells was freely reversible, since the bacteria recovered upon dilution of the inhibitory agent. This could also be the case for substance D91, as a high percentage of cells recovered after a 3-5 h incubation in its presence. Early studies on the mode of action of colicins $\mathrm{E} 1$ and $\mathrm{K}$ implicated the cytoplasmic membrane as a primary target. These bacteriocins inhibit protein and nucleic acid biosynthesis, uncouple electron transport from active transport, and cause $\mathrm{K}^{+}$leakage in susceptible cells. Their action has often been compared to that of phage ghosts. The hole puncture repair 
hypothesis postulated to explain the events occurring after phage or ghost infection was proposed by Luria (1964) for the membrane-active colicins. Membrane depolarization would result from the insertion of colicin molecules into the cytoplasmic membrane where they form transient non-specific channels of finite size (Schein et al., 1978). This model could be applied to staphylococcins having the same mode of action, including the antagonistic substance D91 described in this study. In spite of its wide spectrum of activity and its bacteriostatic action, this substance is analogous to many bacteriocins in terms of function and chemical properties.

\section{REFERENCES}

Dajani, A. S. \& Wannamaker, L. W. (1973a). Kinetic studies on the interaction of bacteriophage type 71 staphylococcal bacteriocin with susceptible bacteria. Joumal of Bacteriology 114, 738-742.

DaJani, A. S. \& WanNamaker, L. W. (1973b). In vitro and in vivo studies on a phage type 71 staphylococcal bacteriocin. In Staphylococci and Staphylococcal Infection, pp. 413-421. Edited by J. Jeljaszewicz. Basel: S. Karger.

DAJANI, A. S. \& TAube, Z. (1974). Plasmid mediated production of staphylococcin in bacteriophage type 71 Staphylococcus aureus. Antimicrobial Agents and Chemotherapy 5, 594-598.

Dajani, A. S., Gray, E. D. \& Wannamaker, L. W. (1970). Effect of bactericidal substance from Staphylococcus aureus on group A streptococci. I. Biochemical alterations. Infection and Immunity 1 , 485-490.

DANDEU, J. P. (1971). Chemical and immunological study of colicins $\mathrm{E} 1, \mathrm{~K}, \mathrm{~A}$, and $\mathrm{Q}$. Infection and Immunity 3, 1-9.

Gagliano, V. J. \& Hinsdill, R. D. (1970). Characterization of a Staphylococcus aureus bacteriocin. Journal of Bacteriology 104, 117-125.

Hale, E. M. \& Hinsdill, R. D. (1973). Characterization of a bacteriocin from Staphylococcus aureus strain 462. Antimicrobial Agents and Chemotherapy 4, 634-640.

Hale, E. M. \& Hinsdill, R. D. (1975). Biological activity of staphylococcin 462: bacteriocin from Staphylococcus aureus. Antimicrobial Agents and Chemotherapy 7, 74-81.

Herschman, H. R. \& Helinski, D. R. (1967). Purification and characterization of colicin E2 and colicin E3. Journal of Biological Chemistry 242, 53605368.

Jetren, A. M. \& Vogels, G. D. (1972a). Nature and properties of a Staphylococcus epidermidis bacteriocin. Journal of Bacteriology 112, 243-250.

Jetten, A. M. \& Vogels, G. D. (1972b). Mode of action of a Staphylococcus epidermidis bacteriocin. Antimicrobial Agents and Chemotherapy 2, 456 463.

JetTen, A. M., Vogels, G. D. \& DE WINDT, F. (1972). Production and purification of a Staphylococcus epidermidis bacteriocin. Journal of Bacteriology 112 , 235-242.
KoNISKY, J. (1982). Colicins and other bacteriocins with established modes of action. Annual Review of Microbiology 36, 125-144.

Kopecky, A. L., Copeland, D. P. \& Lusk, J. E. (1975). Viability of Escherichia coli treated with colicin K. Proceedings of the National Academy of Sciences of the United States of America 72, 46314634.

LURIA, S. E. (1964). On the mechanism of action of colicins. Annales de l'Institut Pasteur 107 (Suppl. 5), 67-73.

Morris, D. M., Lawson, J. W. \& Rogolsky, M. (1978). Effect of a staphylococcin on Neisseria gonorrhoeae. Antimicrobial Agents and Chemotherapy 14, 218-223.

ODEBerg, H. \& Olsson, I. (1976). Mechanisms for the microbial activity of cationic proteins of human granulocytes. Infection and Immunity 14, 1269-1275.

Rogolsky, M. \& WILEY, B. B. (1977). Production and properties of staphylococcin genetically controlled by the staphylococcal plasmid for exfoliative toxin synthesis. Infection and Immunity 15, 726-732.

Rosen, B. P. \& KASHKET, E. R. (1982). Energetics of active transport. In Bacterial Transport, pp. 559-620. Edited by B. P. Rosen. New York \& Basel: Marcel Dekker.

Schein, S. J., Kagan, B. L. \& Finkelstein, A. (1978). Colicin $K$ acts by forming voltage dependent channels in phospholipid bilayer membranes. Nature, London 276, 159-163.

WARren, R., ROGOLSKY, M., WILEY, B. B. \& GlasGow, L. A. (1974). Effect of ethidium bromide on elimination of exfoliative toxin and bacteriocin production in Staphylococcus aureus. Journal of Bacteriology 118, 980-985.

WeErkamp, A., Geerts, W. \& Vogels, G. D. (1977). Conditional killing effect of staphylococcin and repair of sublethal injury in Staphylococcus aureus. Antimicrobial Agents and Chemotherapy 12, 314-321.

WeErKamp, A., HeINEN-Von Borries, U. J. \& Vogels, G. D. (1978). Biochemical and ultrastructural changes in Staphylococcus aureus treated with staphylococcin 1580. Antonie van Leeuwenhoek 44, 35-48. 